\title{
Analysis of reservoir parameters on the basis of well logging and DST of Miocene gas reservoirs in the central part of the Carpathian Foredeep, Poland
}

\author{
Michał Maruta, Marek L. Solecki*, Katarzyna Chruszcz-Lipska, \\ Katarzyna Stachowicz, Stanisław Dubiel, Adam Zubrzycki \\ AGH University of Science and Technology, Faculty of Drilling, Oil and Gas, Mickiewicza Ave 30, 30-059 Kraków, \\ Poland \\ *corresponding author; e-mail: mlsoleck@agh.edu.pl
}

\begin{abstract}
In the Polish part of the Carpathian Foredeep, an intensification of gas exploration and exploitation from Miocene strata took place in the middle of the twentieth century. In spite of a good degree of geological and reservoir recognition, the area of the Carpathian Foredeep is still considered to be prospective for the discovery of new gas reservoirs. Here we analyse statistically selected reservoir parameters of Miocene deposits, such as total porosity, effective permeability and reservoir water inflow. These parameters have been determined on the basis of interpretations of results of well logs and reservoir tests with tubular bed samplers (DST, Drill Stem Test). Analytical results in the form of regression and dependence of the logarithm of permeability as a function of porosity show a weak correlation. However, in the study area, the distribution of porosity values for Miocene strata is close to normal.
\end{abstract}

Key words: statistics, porosity, permeability, water inflow, sandstones, Poland

\section{Introduction}

In the Carpathian Foredeep, intensive exploration and exploitation of gas from Miocene strata have been carried out since the mid-1950s (Karnkowski, 1999; Myśliwiec, 2004a). The main reservoir rocks are Miocene silty sandstones with numerous interiors of silt and shale. In the area of the Carpathian Foredeep, 84 gas reservoirs have now been documented, containing approximately 27 per cent of Polish gas resources (Szuflicki et al., 2020). Although there is a good degree of geological and reservoir recognition, this particular area is still considered to be prospective for the discovery of new gas reservoirs.
The main objective of the present paper was a statistical analysis of selected reservoir parameters of Miocene deposits, such as porosity, effective permeability and reservoir water inflow, as determined on the basis of interpretations of results of field tests (acoustic logs and reservoir tests with tubular bed samplers [DST - Drill Stem Test]), which were performed simultaneously. The results of these analyses, in the form of regression equations, can aid in, among other things, to forecast reservoir conditions and simulations of various gas exploitation methods in the study area. 


\section{Geological setting and occurrence of gas reservoirs}

The Carpathian Foredeep is a Neogene piedmont trough that formed during the fold-thrust movements of the Outer Carpathians (flysch) during the last stages of the Carpathian tectogenesis (Stupnicka \& Stempień-Sałek, 2016; Mizerski, 2020). In Poland, this unit measures about $300 \mathrm{~km}$ in length and up to $100 \mathrm{~km}$ in width, as part of a large sedimentary basin that extends along the outer part of the Carpathians. In the west it connects with the Alpine molasse basin and in the east with the Balkanides piedmont trough. Structurally, this is an asymmetrical piedmont trough that shallows towards the north and is filled mainly with clastic strata of Miocene (Badenian-early Sarmatian) age, reaching a maximum thickness of up to $3,000 \mathrm{~m}$ in the Przemyśl-Lubaczów zone (Wielkie Oczy trench). The northern boundary of the Carpathian Foredeep has an erosive character; the southern one is tectonic, routed through the forehead of the Outer Carpathians, thrusted on Miocene sedimentary units. Some of these rocks lie tectonically intact (i.e., are autochthonous strata of Miocene age), while others have been uprooted, folded together with Carpathian folds and put on indigenous sediments (allochthonous deposits of Miocene age: Stebnik and Zgłobice thrust sheets) (Fig. 1) (Oszczypko, 2006; Stupnicka \& Stempień-Sałek, 2016).

The most important productive series in the Miocene sequence of the Carpathian Foredeep are the sandstone levels of the autochthonous deposits. They occur in the molasse complex of varying thickness in the research area: from 2,000 $\mathrm{m}$ in the southern zone (in front of the forehead of the Carpathian flysch overthrust) and up to several hundred metres in the marginal zones - north and north-east, resting on the age-varied Mesozoic-Palaeozoic basement of the western European platform. The molasse complex consists of Badenian and lower Sarmatian sedimentary rocks in the form of fine- and medium-grained sandstones (often scattering), as well as silt and shale. Reservoir rocks containing natural gas accumulations are the following: Baranów sandstones and occasionally evaporatic deposits of Badenian age, as well as turbiditic sediments of the basin floor and submarine fans and Dzików sandstones of early Sarmatian date (northeastern zone). The best and most abundant reservoirs for natural gas are sandstones of submarine fans and deltaic deposits. These rocks contain the largest natural gas reservoirs in the Carpathian Foredeep. Sandy deposits of submarine fans prevail in the southern part of the foredeep; towards the north, these pass into fine-grained sediments, up to deltaic levels near the top of the sequence. The latter are the main reservoir series in the northeastern part of the Carpathian Foredeep. Their thickness amounts to up to several hundred metres; the series is characterised by the occurrence of a sequence of very good reservoir rocks interbedded by clay levels (Myśliwiec, 2004a, b).

In spite of having many individual features, natural gas accumulations in the Carpathian Foredeep
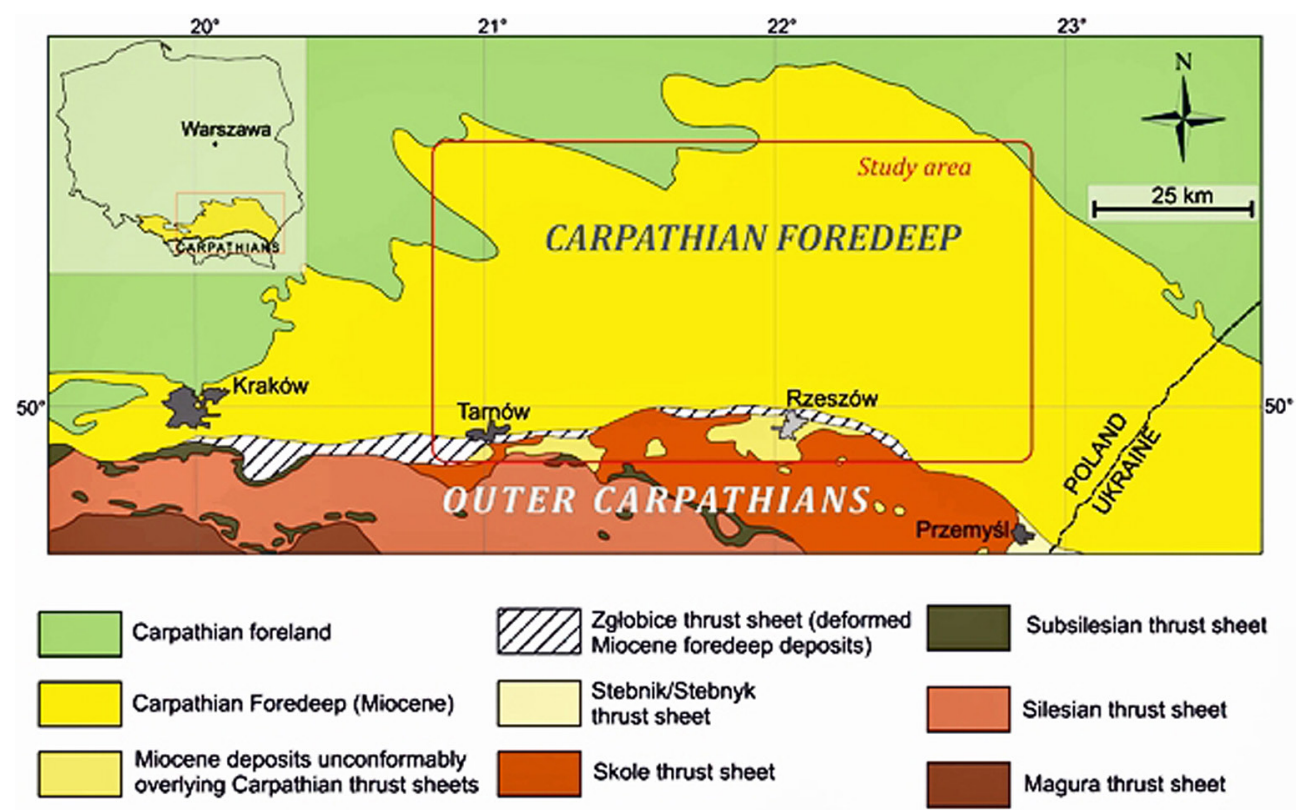

Fig 1. Tectonic sketch of the Polish portion of the Outer Carpathians and Carpathian Foredeep (modified from Oszczypko, 2001) 
display several common features, as well as sealing. The pre-Neogene surface of disconformity and tectonic folding of the flysch Carpathians performs the role of regional sealer (structural closure) on the scale of the entire foredeep. Their shape was influenced by tectonic movements that differentiated along dislocations, as well as intense erosion.

\section{Statistical analysis of reservoir parameters of Miocene sandstone deposits determined on the basis of sampling}

Gas-bearing and aquifer reservoirs of autochthonous Miocene strata in the Carpathian Foredeep are characterised by significant facies variability, both horizontal and vertical. The layer-and-laminate structure of the sandstone-silt-clay sequence and frequent thickness reductions led to the occurrence of diversified saturation with reservoir fluids (reservoir water and natural gas). For this reason, results of sampling such occurrences works, obtained during the exploration stage, may be ambiguous.

The reservoir properties of Miocene deposits in the study area were investigated by acoustic well logging and drill stem tests (DST). The results of these tests are used in the oil industry to make decisions regarding exploration and technology. Industrial practice has shown that reservoir properties and parameters from the interpretation of geophysical well logging (Drabina, 2017) and DST are most easily available.

Industrial gas accumulation occurs mainly in sandstone levels; however, gas saturation is also found in finely laminated sandy-clay or even siltshale levels. Correct recognition of reservoir features of these sediments is crucial for typifying potential zones of gas accumulation in Miocene deposits. In order to be able to assess reservoir parameters, results of technically and technologically successful reservoir tests (DST) of water-bearing Miocene deposits, obtained in the 1990s (Dubiel et al., 1993-1998), have been used.

\subsection{Distribution and statistical analysis of reservoir parameters}

The distribution of selected reservoir parameters, i.e., total porosity of rocks $\left(\varphi_{\text {geoph }}\right)$, reservoir water inflow $\left(Q_{w}\right)$ and effective permeability for water $\left(\mathrm{k}_{\mathrm{w}}\right)$, are presented in the form of histograms (Fig. $2 \mathrm{~A}-\mathrm{C})$. In addition, basic statistical data are included in Table 1.

Total porosity of rocks, determined by geophysical well logging $\left(\varphi_{\text {geoph }}\right)$, is the basic reservoir property of liquid resources. The values of porosity of Miocene levels in the study area (75 measurements) are in the range of 2 to 20 per cent, the mean value is 9.3 per cent, and the median is 8.0 per cent (Fig. 2A, Table 2). The histogram of porosity values is close to the normal distribution; it is not a typical distribution of this parameter. For example, Leśniak et al. (2007) did not observe such a relationship in Miocene sandstones in the Rzeszów area (Poland).

Water inflow to the sampler $\left(Q_{w}\right)$. Analysis of industrial data shows that in the largest number of cases of Miocene sampling (about 80 per cent), an inflow of reservoir water without traces of natural gas was obtained, with traces of gas or slightly gassed. In this water occasionally there were also small amounts of mud filtrate or even drilling mud. The histogram of values of deposit water inflow during tests (DST) is shown in Figure 2B. The average flow rate of reservoir water to the sampler is 2.861 , the median being $1.100 \mathrm{~m}^{3} / \mathrm{h}$ (Table 2). The distribution of the average flow rate of reservoir water in the study area shows a strong right-sided asymmetry (skewness: 3.101), which indicates that the majority of observed results have values lower than the average.

Effective permeability of Miocene deposits for reservoir water $\left(\mathrm{k}_{\mathrm{w}}\right)$. In order to determine the effective permeability of Miocene deposits for water based on the results of short-term DST tests, the Horner method was most often used as the most useful interpretation of bottom-pressure reconstruction curves recorded about 60 to 90 minutes. The log-log method (Dubiel et al., 2003) was also often used to interpret bottom-pressure restoration tests that lasted more than 90 minutes. The histogram of

Table 1. Descriptive statistics

\begin{tabular}{cccrrrr} 
Parameter & Number of measurements & Arithmetic mean & Median & Minimum & Maximum & Standard deviation \\
\hline$\varphi_{\text {geoph. }}[\%]$ & 75 & 9.30 & 8.00 & 2.00 & 20.00 & 3.833 \\
$\mathrm{k}_{\mathrm{w}} \times 10^{-15}\left[\mathrm{~m}^{2}\right]$ & 70 & 73.10 & 11.00 & 0.010 & 669.00 & 152.994 \\
$\mathrm{Q}_{\mathrm{w}}\left[\mathrm{m}^{3} / \mathrm{h}\right]$ & 67 & 2.86 & 1.100 & 0.010 & 25.30 & 4.446 \\
\hline
\end{tabular}



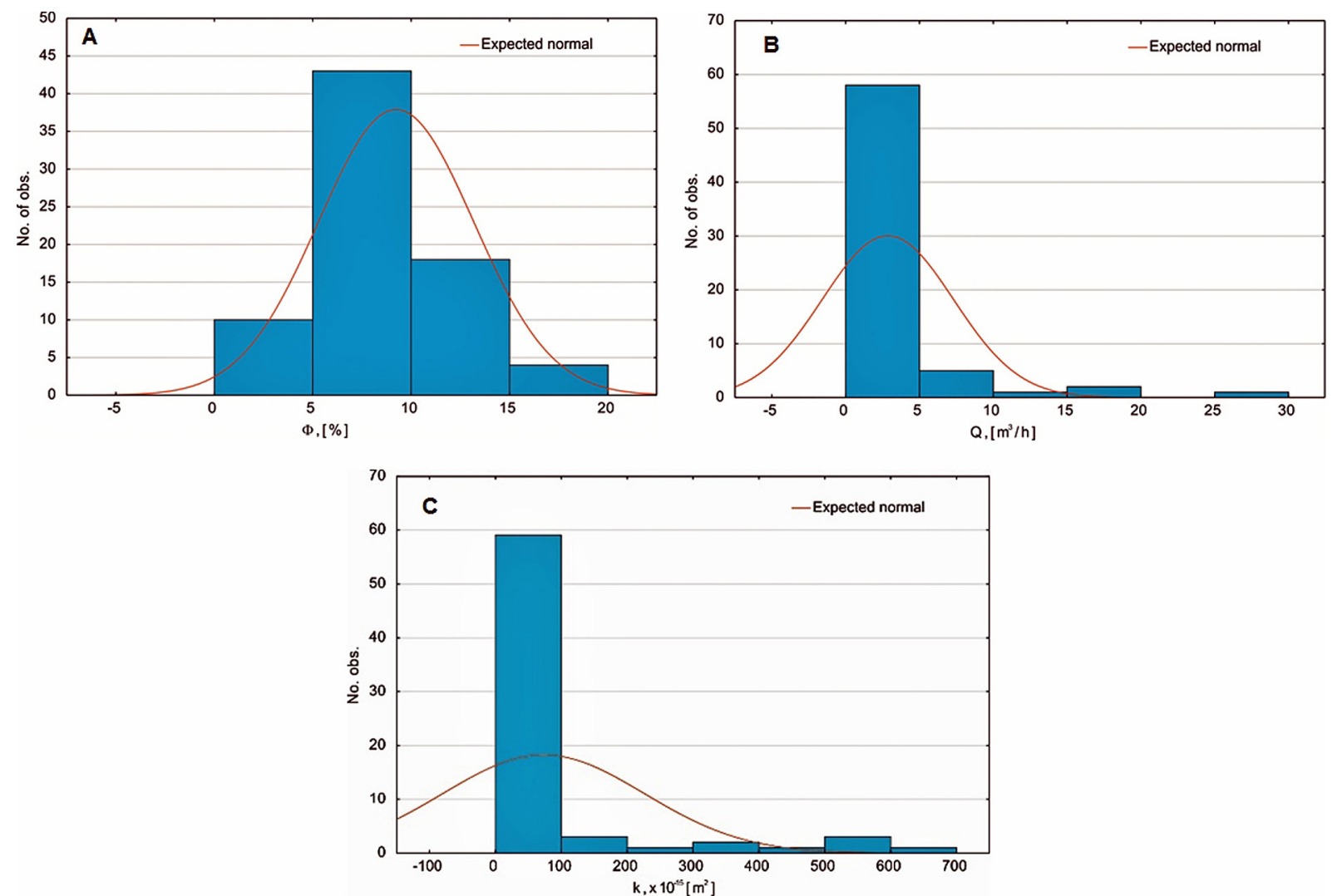

Fig. 2. Distribution of values: A - Porosity; B - Expense of reservoir water inflow; C - Effective permeability for reservoir water

Table 2. List of statistics parameters for studied dependencies of two variables concerning Miocene strata in the Carpathian Foredeep

\begin{tabular}{cccccc}
\hline $\begin{array}{c}\text { Tested } \\
\text { dependence }\end{array}$ & $\begin{array}{c}\text { Number of } \\
\text { measurements }\end{array}$ & Regression equation & $\begin{array}{c}\text { Correlation coefficient } \\
\text { calculated } \\
\text { value }\end{array}$ & $\begin{array}{c}\text { critical } \\
\text { value }\end{array}$ & $\begin{array}{c}\text { Range of values of the tested } \\
\text { parameters }\end{array}$ \\
\hline $\log \left(\mathrm{k}_{\mathrm{w}}\right)=\mathrm{f}(\varphi)$ & 69 & $\log \left(\mathrm{k}_{\mathrm{w}}\right)=0.629+0.070 \varphi$ & 0.4625 & 0.2500 & $\begin{array}{c}\mathrm{k}_{\mathrm{w}} \in(0,1-700) \times 10^{-15}\left[\mathrm{~m}^{2}\right] \\
\varphi \in(2-20)[\%]\end{array}$ \\
$\mathrm{p}_{\mathrm{z}}=\mathrm{f}\left(\mathrm{H}_{\mathrm{m}}\right)$ & 66 & $\mathrm{p}_{\mathrm{z}}=-0.10905+0.0095 \mathrm{H}_{\mathrm{m}}$ & 0.9926 & 0.2500 & $\begin{array}{c}\mathrm{p}_{\mathrm{z}} \in(5-26)[\mathrm{MPa}] \\
\mathrm{Q}_{\mathrm{w}}=\mathrm{f}\left(\mathrm{K}_{\mathrm{d}}\right)\end{array}$ \\
\hline
\end{tabular}

$1[\mathrm{mD}]=0.986923 \times 10^{-15}\left[\mathrm{~m}^{2}\right]$.

the effective permeability determined on the basis of DST tests is shown in Figure 2C. The average effective permeability is $73.099 \times 10^{-15} \mathrm{~m}^{2}(74.068 \mathrm{mD})$ (Table 2). The distribution of permeability values in the study area shows a strong right-sided asymmetry (skewness: 2.673), which means that the majority of measurements showed values lower than the average.

\subsection{Prediction of reservoir parameters of Miocene rocks in the Carpathian Foredeep}

\subsubsection{Effective permeability as a function of total porosity}

The clastic reservoir rocks (sandstones, siltstones) are characterised by a general proportionality of 
effective permeability to porosity. This proportionality is diversified and depends on the mineralogical type of sandstone, their texture and the course of the diagenetic process during geological time. In depth profiles, these parameters are most easily available from quantitative assessments of drilling geophysics and results of field tests carried out in the course of oil exploration at the stage of drilling exploration (Zubrzycki \& Dubiel, 2010).

The relationship between:

$$
\log \mathrm{k}_{\mathrm{w} . \mathrm{DST}}=\mathrm{a}+\mathrm{b} \cdot \varphi_{\text {geoph. }}
$$

was studied using statistical methods (where: $\mathrm{k}_{\mathrm{w} \text {.DST }}$ - effective coefficient of rock permeability for water, $[\mathrm{mD}] ; \varphi_{\text {geoph. }}-$ rock porosity coefficient [\%]). The values of $k_{w \text {.DST }}$ were determined on the basis of field tests by the methods: Horner and log-log (Dubiel et al., 2003), while the values $\varphi_{\text {geoph. }}$ and the intervals studied were obtained by geophysical well logging. The following regression equation was obtained by us (determined for a confidence interval of 95 per cent, at a significance level of 0.05 [Zieliński, 1972]):

$$
\log \mathrm{k}_{\mathrm{w} . \mathrm{DST}}=0.629+0.070 \varphi_{\text {geoph. }}[\mathrm{mD}]
$$

Statistical analysis conducted for the present paper of a large set of data (69 measurements) showed a weak correlation between the variables analysed. For a confidence interval of 0.95 , the correlation coefficient $\mathrm{R}$ is 0.4625 (Table 2).

However, literature data (Zubrzycki \& Dubiel, 2010) show a significant relationship between permeability and porosity for autochthonous Miocene sandstone formations of the Carpathian Foredeep (i.e., southern and northeastern zones). Zubrzycki \& Dubiel (2010) analysed 32 samples and presented the following results:

$$
\log k_{\mathrm{w} . \mathrm{DST}}=0.174+0.101 \varphi_{\text {geoph. }}[\mathrm{mD}]
$$

and

$$
\log \mathrm{k}_{\mathrm{w} . \mathrm{DST}}=0.242+0.0882 \varphi_{\text {geoph. }}[\mathrm{mD}]
$$

with the correlation coefficient $\mathrm{R}=0.814$ for a depth of $168-2,273 \mathrm{~m}$ (equation 2 ) and $\mathrm{R}=0.699$ for a depth of 103-1,082 m (equation 3).

The lower correlation coefficient obtained by us most probably results from the fact that the industrial data set concerns a much larger area of the Carpathian Foredeep than the area included in the above-mentioned paper (Zubrzycki \& Dubiel, 2010).

\subsubsection{Reservoir pressure $p_{z}$ as a function of depth of reservoir rocks}

For the Upper Jurassic-Lower Cretaceous in the central part of the Carpathian Foredeep, based on 68 reservoir tests, Dubiel \& Uliasz-Misiak (2012) analysed the dependence of reservoir pressure as a function of depth of measurement using a tube sampler. For the dependence studied, a linear model was chosen: $y=a x+b$. The following linear regression equation was obtained:

$$
\mathrm{p}_{\mathrm{z}}=0,00992 \mathrm{H}_{\mathrm{m}}-0.1522[\mathrm{MPa}]
$$

- $\mathrm{H}_{\mathrm{m}}$ - the depth of placement of recording depth gauge, $[\mathrm{m}]$.

When comparing the calculated value of the correlation coefficient $\mathrm{R}=0.9900$ with the critical value of this coefficient $R_{\alpha}=0.2387$, for a significance level $\alpha=0.05$ and confidence interval 0.95 , it can be concluded that this model is very well suited for predicting the value of reservoir pressure $\left(\mathrm{p}_{\mathrm{z}^{\prime}} \mathrm{MPa}\right)$ at a given depth $\left(\mathrm{H}_{\mathrm{m}^{\prime}} \mathrm{m}\right)$. For example, at a depth $\mathrm{H}_{\mathrm{m}}=400-3,000 \mathrm{~m}$ (Dubiel \& Uliasz-Misiak, 2012).

The analysis of dependence of reservoir pressure as a function of depth of measurement for Miocene strata of the Carpathian Foredeep analysed in the present paper (for 66 reservoir tests performed by a tube sampler) showed, similar to the Upper Jurassic-Lower Cretaceous, a very good correlation of these variables, $R=0.9945$. The determined linear regression equation is shown below:

$$
p_{z}=-0.10905+0.0095 H_{m}[m] \text {. }
$$

This equation is suitable for predicting the value of reservoir pressure for a given value of the depth of measurement.

Water flow $\left(\mathrm{Q}_{\mathrm{w}}\right)$ depending on the initial pressure depression coefficient $\left(\mathrm{K}_{\mathrm{d}}\right)$ produced during the DST test.

This dependence enables the selection of a minimum value of the differential pressure in order to obtain the flow of reservoir fluid to a sampler with a representative volume in a given time of waiting for the inflow. At the same time, the ratio of pressure depression $K_{d}$ is understood as the ratio of hydrostatic pressure transfer fluid $\left(\mathrm{p}_{\mathrm{hp}}\right)$ in the test column to the reservoir pressure $\left(p_{z}\right)$. It should be noted that 
the smaller the value of this quotient, the higher the value of the differential pressure. At the same time, creating a pressure difference that is too large can cause instability of the Miocene strata and lead to blockage of the perimeter zone with sand grains and clay particles.

Based on an analysis of the results of the selected 22 reservoir tests (DST) obtained from the holes located north of Tarnów, a satisfactory correlation was obtained, determining the following regression equation (Dubiel \& Uliasz-Misiak, 2012):

$$
\mathrm{Q}_{\mathrm{w}}=-6,255 \mathrm{~h} \mathrm{~K}_{\mathrm{d}}-3,8357\left[\mathrm{~m}^{3} / \mathrm{h}\right]
$$

The calculated value of the correlation coefficient $R=0.5596$, the critical value $R_{\alpha}=0.4143$ at a significance level $\alpha=0.05$ and confidence level 0.95.

Statistical analysis of the data studied here, unfortunately, did not indicate a correlation of variables such as water expenditure $\left(Q_{w}\right)$ depending on the initial pressure depression coefficient $\left(\mathrm{K}_{\mathrm{d}}\right)$ produced during the reservoir test (DST) (Table 2). This is probably due to the fact that the industrial data set concerns a much larger area of the Carpathian Foredeep than the area included in the paper by Dubiel \& Uliasz-Misiak (2012).

The reasons for the lack of correlation of the entire area of the Carpathian Foredeep can be variable geological conditions (e.g., significant lithological and facies heterogeneity of Miocene strata, twophase flow of reservoir fluid - water with gas), as well as technological sampling in the area studied.

\section{Conclusions}

The distribution of porosity values of Miocene strata is close to normal, while the distribution of water efficiency and rock permeability in the study area show a strong right-sided asymmetry.

The regression equation determined for the dependence of reservoir pressure as a function of the depth of its measurement is suitable for forecasting $(R=0.9945)$. The dependence of the logarithm of effective permeability as a function of total porosity shows a weak correlation. However, some literature data document a significant relationship between these two parameters in Miocene reservoir rocks of the Carpathian Foredeep.

The significant spread of measured data may be caused by the fact that too large area of the Carpathian Foredeep, characterised by significant variability of reservoir parameters, was chosen for analysis.

\section{Acknowledgements}

This work has been performed within the statutory research programme of the Faculty of Drilling, Oil and Gas AGH UST No. 16.16.190.779.

\section{References}

Drabina, A., 2017. Metody wyznaczenia porowatości ogólnej na podstawie profilowań geofizyki otworowej w utworach klastycznych i węglanowych [Methods of determining total porosity based on well logs in sedimentary and carbonate rocks]. Prace Instytutu Mechaniki Górotworu PAN, 2, 13-24.

Dubiel, S. \& Uliasz-Misiak, B., 2012. Wpływ ciśnienia różnicowego na wydatek wody złożowej podczas badań rurowymi próbnikami złoża utworów miocenu autochtonicznego $\mathrm{w}$ zapadlisku przedkarpackim [Influence of differential pressure on formation water flow rate during tests of the autochtonous Miocene deposits in the Carpathian Foredeep with DST]. Gospodarka Surowcami Mineralnymi 28, 157-171.

Dubiel, S., Chrząszcz, W. \& Rzyczniak, M., 2003. Problemy opróbowania warstw perspektywicznych rurowymi próbnikami ztoża [Problems of pay zones testing with drill stem testers]. Uczelniane Wydawnictwo Naukowo-Dydaktyczne AGH, Kraków, 223 pp.

Dubiel, S., Rzyczniak, M., Wójtowicz, T., Nowakowski, Z. \& Kułaga, T., 1993-1998. Analiza i interpretacja wyników opróbowań warstw perspektywicznych rurowymi próbnikami złoża wykonywanych przez OPNiG Kraków [Analysis and interpretation of the results of sampling of perspective layers with Drill-Stem Test (DST) performed by OPNiG Kraków]. Akademia Górniczo-Hutnicza im. S. Staszica w Krakowie. Wydział Wiertnictwa, Nafty i Gazu. Kraków, 20-63.

Karnkowski, P., 1999. Złoża gazu ziemnego i ropy naftowej $w$ Polsce [Oil and gas deposits in Poland]. GEOS, $380 \mathrm{pp}$.

Leśniak, G., Such, P., Dziadzio, P., 2007. Reservoir Properties of Miocene Sandstones in Rzeszow Area (Carpathian Foredeep, Poland). [In:] Lacombe O., Roure F., Lavé J., Vergés J. (Eds): Thrust Belts and Foreland Basins. Frontiers in Earth Sciences. Springer, Berlin, Heidelberg. https://doi.org/10.1007/978-3-540-694267_21

Mizerski, W., 2020. Geologia Polski [Geology of Poland]. Wydawnictwo Naukowe PWN. Warszawa, 311 pp.

Myśliwiec, M., 2004a. Mioceńskie skały zbiornikowe zapadliska przedkarpackiego [The Miocene reservoir rocks of the Carpathian Foredeep]. Przeglad Geologiczny 52, 581-592.

Myśliwiec, M., 2004b. Typy pułapek gazu ziemnego i strefowość występowania ich złóż w osadach miocenu wschodniej części zapadliska przedkarpackiego [Traps for gas accumulations and the resulting zonation of the gas fields in the Miocene strata of the eastern part of the Carpathian Foredeep (SE Poland)]. Przegląd Geologiczny 52, 657- 664. 
Oszczypko, N., 2001. Rozwój zapadliska przedkarpackiego $\mathrm{w}$ miocenie [The Miocene development of the Polish Carpathian Foredeep]. Przeglad Geologiczny 49, 717-723.

Oszczypko, N., 2006. Powstanie i rozwój polskiej części zapadliska przedkarpackiego [Development of the Polish sector of the Carpathian Foredeep]. Przeglad Geologiczny 54, 396-403.

Stupnicka, E. \& Stempień-Sałek, M., 2016. Geologia regionalna Polski [Regional geology of Poland]. Wydawnictwo Uniwersytetu Warszawskiego. Warszawa, 339 pp.

Szuflicki, M., Malon, A. \& Tymiński, M. (Eds), 2020. Bilans zasobów złóż kopalin w Polsce wg stanu na 31 XII $2019 r$. [The balance of mineral resource deposits in Poland as of 31 XII 2019]. Państwowy Instytut Geologiczny Państwowy Instytut Badawczy, Warszawa, 497 pp.

Zieliński, R., 1972. Tablice statystyczne [Statistical tables]. PWN, Warszawa, 390 pp.

Zubrzycki, A. \& Dubiel, S., 2010. Analiza właściwości zbiornikowych utworów miocenu autochtonicznego zapadliska przedkarpackiego na podstawie wyników opróbowań złożowych i geofizyki wiertniczej [Analysis of reservoir properties of autochthonous Miocene deposits in the area of Carpathian Foredeep on the basis of DST and well logging]. Wiertnictwo, Nafta, Gaz 27, 121-127.

Manuscript received: 20 October 2020

Revision accepted: 20 November 2020 